\title{
Quantification of dominance for proteins pleiotropically affected by opaque-2 in maize
}

\author{
C. DAMERVAL \& D. DE VIENNE \\ Station de Génétique Végétale, Université Paris-Sud/CNRS/INRA, La Ferme du Moulon, 91190, Gif-sur-Yvette, France
}

\begin{abstract}
The maize opaque-2 (o2) mutation is known to have numerous pleiotropic effects. Using two different genetic backgrounds, endosperm proteins from isogenic lines of the $o 2$ locus and their reciprocal hybrids were compared by high-resolution two-dimensional electrophoresis (2-D PAGE), and the 2-D gels stained with Coomassie blue or silver were analysed using a computerassisted system for quantification of polypeptide spots. The aim of this work was (i) to identify polypeptides, the amount of which is affected by the single gene substitution, and (ii) to assess the dominance relations for every affected polypeptide. The triploid nature of the endosperm allowed the effects of $0,1,2$ and 3 doses of the wild-type $O 2$ allele to be examined. When using a basic $\mathrm{pH}$ range in the first dimension (IEF), we observed the known effects of $o 2$ on prolamin storage proteins, mostly being $22 \mathrm{kDa}$, zeins. In a pH 5-7 IEF range, we detected 14 polypeptides whose amount is affected by the $o 2$ mutation in both backgrounds. Eight of them were more abundant in the wild type than in the mutant and six were more abundant in the mutant than in the wild type. Dominance of the wild type allele was found for the amounts of 10 polypeptides, while the amounts of two of them displayed additive inheritance. This is an example where pleiotropically related characters display different inheritance, which could generate heterozygous phenotypes with original properties as compared to their homozygous parents. Because $\mathrm{O} 2$ belongs to the basic region-leucine zipper family of transcription activators, our results show that 2-D PAGE of isogenic lines represents a straightforward method to identify gene products affected by a transcription factor, whether they are products of its target genes, or products indirectly affected by far-reaching effects. This is a prerequisite to understanding the multiple molecular and physiological consequences of the action of such factors.
\end{abstract}

Keywords: dominance, isogenic lines, maize, opaque-2, pleiotropy.

\section{Introduction}

Numerous single mutations are known that have multiple phenotypic consequences (Caspari, 1952; Wright, 1968). Various mechanisms can be put forward to explain pleiotropy. For example, a mutation of a gene coding for a trans-acting transcription factor binding to the promoter regions of different genes could result in variation of the characters they control (Hope \& Struhl, 1985; Sassone-Corsi, 1985). At the post-translational level, it has been shown that differences in the degree of sialylation of multiple hydrolases could be due to the mutation of the gene coding for neuraminidase (Womack et al., 1981). Keightley \& Kacser (1987) investigated a branched metabolic pathway where the two outputs represent two characters whose variation is affected by changes in any of the genetically specified enzymes in the system. However, characterization of the mutation may not be sufficient to predict or understand all the diverse pleiotropic effects. Recent cloning of the $r$ (rugosus) gene in pea revealed that it encodes a starch-branching enzyme, which does not explain in a simple way its effects on legumin biosynthesis and lipid accumulation (Bhattacharyya et al., 1990).

On the other hand, the question of whether characters pleiotropically related display different types of inheritance is important not only because it can shed light on the physiological relationships between the different effects, but also because it would imply that heterozygosity generates phenotypes which are not in the range of the parental variation, which can have implications in quantitative or population genetics. A well-known example of such a situation is that of sickle cell anaemia in man: the $H b^{s}$ allele is recessive to the wild type allele for the sickling phenomenon, codominant for the amount of globin $\mathrm{S}$, while there is almost complete recessivity for anaemia and dominance 
for malaria resistance. This results in overdominance for viability in malaria-infested environments (Allison, 1955 and 1964). Even though overdominance is not commonly seen, various examples where related traits display different inheritance have been reported in animals (reviewed in Caspari, 1952 and Keightley \& Kacser, 1987) and in plants. For instance the $R i$ allele in Oenothera is recessive for tumour-like proliferations, and co-dominant for the rolling up of the leaves (von Weidner, 1950). These cases would not be representative of what is supposed to be observed when the mutation is at an enzyme locus. With the above mentioned branched pathway model for pleiotropy, Keightley \& Kacser (1987) showed that if saturation and feedback inhibition are absent, all fluxes (i.e. phenotypes) have identical dominance relations. According to the authors, this result would explain why many mutations have similar inheritance for the characters they affect pleiotropically.

In maize, the opaque-2 (o2) mutation, in addition to modification of endosperm appearance, increases tryptophan and lysine contents and decreases the amount of zein, especially the $22 \mathrm{kDa}$ class (Mertz et al., 1964; Lee et al., 1976; Di Fonzo et al., 1977). Other storage proteins, globulins, albumins and glutelins are more abundant in $o 2$ mutants (Christianson et al., 1974; Misra \& Mertz, 1975; Lee et al., 1976; Di Fonzo et al., 1977; Dierks-Ventling, 1981). The net photosynthetic assimilation rate of seedlings (MorotGaudry et al., 1979), yield (Lambert et al., 1969) and disease resistance (Loesch et al., 1976) are reduced, as the duration of protandry (Gupta, 1979). Cloning and sequencing the gene showed that the $\mathrm{O} 2$ protein belongs to one of the three known families of transcriptional factors, the basic region-leucine zipper family (Hartings et al., 1989; Schmidt et al., 1990; Varagona et al., 1991), some members of which have been shown to control different genes (Hope \& Struhl, 1985). Such a function would be consistent with the various effects previously reported. If the $\mathrm{O} 2$ protein is not limiting, and in an isogenic context, dominance should be observed for all characters affected by o2. To our knowledge, this has not been systematically investigated for $o 2$.

As shown by Gottlieb \& de Vienne (1988) and de Vienne \& Gottlieb (1990), comparison of isogenic lines by two-dimensional polyacrylamide gel electrophoresis (2-D PAGE, O'Farrell, 1975) allows the quantification of the effects of a single mutation on the class of relatively abundantly expressed proteins, which can be a valuable aid in understanding the ramifications of a given mutation and assessing its overall impact on the organism. Using morphological mutants in pea as examples, they showed that some substitutions are associated with far-reaching effects on the physiology of the organism, as reflected by modifications of many of the abundant proteins, while others are not.

Considering the mutation $o 2$ as a model system, we investigated, by 2-D PAGE of mature endosperm proteins, the effects of a single mutation on protein accumulation by using two pairs of isogenic lines of maize, one obtained by backcrossing, the other where o2 spontaneously appeared. Within each background, the inheritance of protein amount variations induced by $o 2$ was analysed in the reciprocal hybrids using a computer-assisted system for quantification of spot intensities. The triploid nature of the endosperm gave the opportunity to examine the effect of $0,1,2$ or 3 doses of the wild type gene on the amounts of affected polypeptides.

\section{Materials and methods}

\section{Plant material}

Kernels of wild type and opaque-2 line W64A (dent type), and wild type and $o 2$ line F2 (flint type), were kindly provided by M. Pollacsek (INRA, ClermontFerrand, France). In the W64A background, o2 appeared as a spontaneous mutation (actual isogenic lines). In F2, the original $o 2$ allele, studied by Mertz (Mertz et al., 1964), was introgressed by eight generations of backcross (near-isogenic lines). The reciprocal hybrids $(\$ O 2 O 2 \times 00202$ and $\$ 02 o 2 \times 00202)$ were available for each background. Three other pairs of near-isogenic lines, also provided by M. Pollacsek, were examined but their reciprocal hybrids were not analysed: F7O2/F7o2 (seven generations of backcross), W182E O2/W182Eo2 (six generations of backcross) and F2O2/F2o2 with another $o 2$ allele (seven generations of backcross).

\section{Protein extraction}

After soaking for $1 \mathrm{~h}$ in water, the embryos and pericarps were removed from mature kernels, and the endosperms were individually ground mechanically in liquid nitrogen. Three procedures for the extraction of total proteins were compared: (i) method described in Damerval et al. (1986) with final protein pellets resuspended in $80 \mu \mathrm{l} \mathrm{mg}^{-1}$ of a basic denaturing detergentrich solution (UKS solution; M. Zivy in Damerval et al., 1986); (ii) direct resolubilization of the meal in $20 \mu \mathrm{l}$ $\mathrm{mg}^{-1}$ of $3 \mathrm{M}$ urea, 2 per cent Pharmalytes $\mathrm{pH} 3-10$, 1 per cent dithiothreitol, 4 per cent Fluorosurfactan100 (Anderson et al., 1985b); (iii) direct resolubilization of the meal in $20 \mu \mathrm{mg}^{-1}$ of UKS solution. On the other hand, the alcohol-soluble zeins were fractionated 
from the other endosperm proteins using the procedure of Wall et al. (1984).

\section{Two-dimensional electrophoresis}

Isoelectric focusing (IEF) was performed in $24-\mathrm{cm}$ long, 1.5-mm diameter rod gels according to Damerval et al. (1987a). Two IEF conditions were used: (i) Pharmalytes $\mathrm{pH}$ 5-8+ Pharmalytes $\mathrm{pH}$ 5-6 (3:1) under $35,000 \mathrm{Vh}$ run, which allows the separation of most proteins; (ii) LKB Ampholines pH 7-9 + Pharmalytes $\mathrm{pH}$ 5-8 (3:1) under 25,000 Vh run, which allows the separation of the zein polypeptides (Righetti et al., 1977; Vitale et al., 1980). Forty microlitres (silverstained gels) or $80 \mu \mathrm{l}$ (Coomassie Blue stained gels) of sample $[\approx 200 \mu \mathrm{g}$ and $\approx 400 \mu \mathrm{g}$ of total proteins respectively, as determined according to Scopes (1974)] were loaded on the basic (former ampholyte range) or acidic (latter ampholyte range) side of the gels.

The pIs of the polypeptides in the most acidic $\mathrm{pH}$ range were determined from IEF gels cut into $1-\mathrm{cm}$ long pieces crushed in degassed distilled water. The $\mathrm{pHs}$ of the successive mixtures were used to plot a standard curve. The effective $\mathrm{pH}$ range was five to seven linear.

The second dimension was as described in Damerval et al. (1987a), in continuous 11 per cent polyacrylamide running gels. Pharmacia low-molecular weight calibration kit was used as marker (Phosphorylase b $94 \mathrm{kDa}$, bovine serum albumin $67 \mathrm{kDa}$, Ovalbumin $43 \mathrm{kDa}$, Carbonic anhydrase $30 \mathrm{kDa}$, Soybean trypsin inhibitor $20.1 \mathrm{kDa}, \alpha$-lactalbumin $14.4 \mathrm{kDa}$ ).

\section{Staining}

All the gels were covalently bound to polyester sheets $\left(\right.$ Gelbond $\mathrm{PAG}^{\circledR}$ ) and stained in series (Granier \& de Vienne, 1986). Silver staining was as described in Damerval et al. (1987a). Colloidal Coomassie Blue staining was modified from Neuhoff et al.(1988). After fixation for $2 \mathrm{~h}$ in 2 per cent phosphoric acid, and 50 per cent ethanol (Anderson et al., 1989), the gels were rinsed with double distilled water $(10 \mathrm{~min})$ followed by 2 per cent phosphoric acid $(2 \times 20 \mathrm{~min})$. They were soaked in 17 per cent methanol, 15 per cent ammonium sulfate, 2 per cent phosphoric acid for 20 min before Coomassie Blue G 250 powder was sprinkled in the bath to a final concentration of $0.1 \mathrm{per}$ cent $\mathrm{w} / \mathrm{v}$. The stain developed by shaking for $72 \mathrm{~h}$ at room temperature.

\section{Western blotting}

Three hundred microlitres of protein extract were run under conditions (i) (see above) into $3 \mathrm{~mm}$ diameter
IEF gels. The gels were equilibrated for $15 \mathrm{~min}$ as described in Damerval et al. (1986). A 2-cm high stacking gel was cast on the top of a continuous 11 per cent polyacrylamide running gel not bound to Gelbond $\mathrm{PAG}^{\circledR}$. After the run, the gels were equilibrated in 25 mM Tris $\mathrm{pH} 8.3,192 \mathrm{~mm}$ glycine and electrotransferred for $30 \mathrm{~min}$ at $12 \mathrm{~V}$ then $1 \mathrm{~h}$ at $24 \mathrm{~V}$ onto a polyvinylidene difluoride membrane (PVDF Immobilon, Millipore) using a Biolyon semi-dry blotting apparatus. Membranes were stained with 0.01 per cent Ponceau S red in 3 per cent trichloroacetic acid to control the quality of the transfer.

Polyclonal antibodies were kindly provided by A. L. Kriz (globulins), R. S. Boston (b-32 protein, who also provided purified b-32) and R. J. Schmidt (O2 protein, who also provided proteins from cells expressing $\mathrm{O} 2$ from bacterial plasmid). For b-32 and globulins, the membranes were briefly destained in methanol, then blocked with Blotto [5 per cent non-fat dry milk in Tris-buffered saline $\mathrm{pH} 7.4$ (TBS)] for $60 \mathrm{~min}$ at $37^{\circ} \mathrm{C}$. They were washed for $3 \times 5$ min with 0.1 per cent nonfat dry milk in TBS, then incubated in 1 per cent non-fat dry milk, 0.05 per cent Tween 20 in TBS with 1:1000 (b-32) or 1:800 (globulins) dilution of antisera for $2 \mathrm{~h}$ at room temperature. The membranes were then washed as before and incubated for $2 \mathrm{~h}$ with the secondary antibody (goat anti-rabbit horseradish peroxidase conjugate, Sigma) at 1:1000 in the same solution as above. After washing, the staining was developed using $8 \mathrm{~mm}$ 4-chloro-1-naphtol, $6 \mathrm{~mm}$ hydrogen peroxide in double-distilled water. Western blotting procedures to detect the $\mathrm{O} 2$ protein were slightly modified, following the recommendations of R. J. Schmidt (personal communication), with $6 \mathrm{~h}$ incubation for the serum anti-O2 (1:700 dilution) and $1 \mathrm{~h}$ incubation for the secondary antibody (1:1000 dilution).

\section{Comparison of the genotypes}

First, the 2-D gels were visually compared by superimposition of the stained dried gels bound to Gelbond $\mathrm{PAG}^{\circledR}$ over a lightbox. Using at least four different individuals per genotype, we detected the polypeptides displaying variations within genotypes, possibly due to residual heterozygosity or to the technique itself. These polypeptides (up to 10 per cent) were not considered further in the analysis.

In a second step spot intensities were automatically quantified using the KEPLER package of Large Scale Biology Corporation (Washington DC, U.S.A.). Low abundance polypeptides were quantified using silverstained gels, while Coomassie Blue stained gels were used for the most abundant polypeptides, to minimize possible staining saturation effects. Gels $(24 \times 20 \mathrm{~cm})$ were digitized using 256 grey levels with a spatial re- 
solution of $100 \mu \mathrm{m}$ using an Eikonix scanner, which generates $2048 \times 2048$ pixel images. The optical density range was $0-1.3$ for silver-stained gels and $0-0.5$ for Coomassie Blue stained gels. Staining background and vertical and horizontal streaks were first removed. The spot detection followed the procedure of M. Zivy (unpublished). The integrated density of the detected spots was fitted according to a 2-D Gaussian distribution. In the spot files obtained, each spot was characterized by its coordinates and the parameters of its Gaussian distribution. The quantified intensity of a spot will be referred as to its 'volume'.

As the endosperms are triploid tissues with two doses of the female genes, the reciprocal hybrids, Owild type $\times 0$ mutant and $\%$ mutant $\times$ ơild-type, were compared to $2: 1$ and $1: 2(\mathrm{v}: \mathrm{v})$ co-electrophoreses of wild type and mutant protein samples, respectively. Three individuals of each of the four genotypes (two parents plus two hybrids) and three samples of each coelectrophoresis were analysed for both staining types, except for Coomassie Blue stained gels of W64A where only two individuals were analysed. To balance possible differences in protein loading or staining level between gels, standardized spot volumes were obtained by dividing spot volumes by the sum of the volumes of about 30 reference spots common to all individuals in each of the four experiments (two backgrounds $\times$ two stainings).

\section{Statistical analyses}

The standardized spot volumes were not normally distributed and a positive correlation was found between the mean and the variance, as classically observed (e.g. Anderson et al., 1985a; Higginbotham et al., 1991). Such a relation could be due to experimental and/or biological reasons. So for the statistical analyses, the standardized volumes were transformed into their decimal logarithm, which made the variables normal and removed the mean-variance relationships (Sokal \& Rohlf, 1969). In case of tight cluster of spots, the analyses were done on the best resolved spot of the cluster. The analyses could only be done in background $\mathrm{F} 2$ for spot $1^{-}$(the spot volumes of wild type and hybrids were 0 in W64A) and in W64A for spot $3^{-}$(poor resolution in F2). The question, whether the measures of spot intensities were proportional to polypeptide amounts, was examined by a linearity test for every polypeptide affected by the mutation. The mutant, the co-electrophoreses $1: 2$ and $2: 1$, and the wild type define a scale of polypeptide amount expected with $0,1,2$, and 3 doses of the wild type allele, respectively. Under the hypothesis of a linear relationship between the standardized volume $Y$ and the number of doses $X$, we have:

$Y=a+b X$

where $b=\operatorname{cov}(X, Y) / \operatorname{var} X$ and $a=\bar{Y}-b \bar{X}$. As a $\log _{10}$ transformation was needed, the linearity test was between $\log _{10} Y$ and $\log _{10}(a+b X)$.

Crossed 2-way ANOvA with interaction were performed with the genetic background as one factor (two levels: F2 and W64A) and the genotype as the other factor. The genotype factor had four levels (wild parent, mutant parent and the two reciprocal hybrids), or three when the spot volume of 02 genotypes was equal to 0 (in the cases where the wild type spot volume was 0 , no statistical analysis was needed because the hybrid spot volumes were also equal to 0 ). When the background effect was significant (or when a genotypic value was 0 in one background), the subsequent analyses were done separately for each background. The genotypic means were compared by $t$-tests.

Estimates of the expected hybrid spot volumes under the hypothesis of additive inheritance were obtained by computing a weighted mean of the coelectrophoresis mean spot volume $(\mathrm{Hc})$ and of the 'theoretical' hybrid spot volume $(H \mathrm{t})$. The latter was:

$H \mathrm{t}=\log _{10}\left(2 / 3 P_{\odot}+1 / 3 P_{\delta^{\prime}}\right)$

where $P_{Q}$ is the mean standardized volume of the female parent spot and $P_{\sigma}$ the mean standardized volume of the male parent spot.

The weighting consisted of making equal the variances of $H \mathrm{c}$ and $H \mathrm{t}$ by using their respective standard deviation as a weighting factor. The variance of $\mathrm{Hc}$ is:

$\theta_{H \mathrm{c}}=\sigma^{2} / n_{\mathrm{c}}$

where $n_{\mathrm{c}}$ is the number of samples analysed for the coelectrophoresis and $\sigma^{2}$ is computed as the residual of a one-way ANOvA with the genotype as a factor (six levels because the two types of co-electrophoreses were taken into account for a best estimation of $\sigma^{2}$ ). The properties of the decimal log-normal law allowed to calculate the variance of $H \mathrm{t}$ :

$\theta_{H \mathrm{t}}=(1 / \operatorname{Ln} 10) \log _{10}\left[\left(\theta / \mu^{2}\right)+1\right]$

where $\theta$ and $\mu$ are, respectively, the variance and mean of the variable $\left(2 / 3 P_{0}+1 / 3 P_{o}\right)$, which follows a decimal log-normal law.

Thus the estimation of the expected hybrid spot volume $\hat{H} c t$ is:

$$
\hat{H} \mathrm{ct}=\left[\left(\hat{H} \mathrm{c} / \sqrt{\theta_{H c}}\right)+\left(\hat{H} \mathrm{t} / \sqrt{\theta_{H \mathrm{t}}}\right)\right] /\left[\left(1 / \sqrt{ } \hat{\theta}_{H \mathrm{c}}\right)+\left(1 / \sqrt{ } \hat{\theta}_{I \mathrm{t}}\right)\right] .
$$


The experimental hybrid spot mean volume, $\hat{H}$, was then compared to $\hat{H}$ ct by a $t$-test $(\alpha=5$ per cent):

$$
\left.(\hat{H}-\hat{H} \mathrm{ct}) / \sqrt{ }\left(\hat{\sigma}^{2} / n_{\mathrm{H}}\right)+2 /\left[\left(1 / \theta_{H \mathrm{c}}\right)+\left(1+\hat{\theta}_{l H \mathrm{t}}\right)\right]^{2}\right\}
$$

where $n_{\mathrm{H}}$ is the number of individuals of the hybrid. The number of degrees of freedom is that of $\sigma^{2}$. When one of the parents had a spot volume equal to 0 , the contrast was between $\hat{H}$ and $\hat{H}$.

Dominance was concluded when the hybrid spot volume was statistically similar to one of the parental spot volume and different from the expected hybrid spot volume $\hat{H} \mathrm{ct}$, and additivity was concluded when the hybrid spot volume was similar to $\hat{H} c t$ and different from the parental spot volumes.

\section{Results}

Isogenic (background W64A) and near-isogenic (background F2) maize lines differing at the $o 2$ locus, and the reciprocal hybrids wild type $\times$ mutant, were analysed by 2-D PAGE of proteins from triploid mature endosperms. Among the extraction procedures compared, the direct resolubilization of the meal in a basic $\mathrm{pH}$ detergent-rich solution gave the best resolution with the largest number of polypeptides.

Up to 500 spots were scored when using a $\mathrm{pH} 5-7$ IEF range. Thirty spots or clusters of spots differed between wild type and mutant F2, and 36 between wild type and mutant W64A. Polypeptides arranged in clusters with similar molecular weight but different, equally spaced isoelectric points ('charge trains', Anderson et al., 1985b), may represent members of protein families. In such cases we analysed the best resolved spot of the set.

Fourteen polypeptides were affected in both backgrounds. Their molecular weights were between 32 and $94 \mathrm{kDa}$ and their isoelectric points ranged from 5.3 to 6.6 (Table 1). Eight were more intense (or detected only) in wild type as compared to the mutant, while six were less intense (or not detected) in wild type as compared to the mutant (Fig. 1). They were numbered $1^{+}$to $8^{+}$and $1^{-}$to $6^{-}$, respectively. Spots $1^{+}, 8^{+}$and $3^{-}$were members of clusters.

Western blotting allowed two of these polypeptides to be identified. Polypeptide $6^{+}$, with a molecular weight of about $35 \mathrm{kDa}$ and allelic form with $\mathrm{pI} \approx 6.4$ in W64A and $\mathrm{pI} \approx 6.0$ in $\mathrm{F} 2$ was protein $\mathrm{b}-32$ (Soave et al., 1981; Di Fonzo et al., 1988). Cluster including $3^{-}$ (molecular weight $\approx 66 \mathrm{kDa}, \mathrm{pI} \approx 6.5-7.0$ ) corresponded to high-molecular weight globulins (data not shown). No polypeptides were detected when using anti-O2 antibodies, either in the wild types or in the mutants, while the controls with bacterial extracts expressing the
$\mathrm{O} 2$ protein were positive. So no hypothesis could be put forward about the nature of either $o 2$ mutations (null allele or allele coding for a defective protein).

Automatic analyses of the 2-D gels were performed to quantify and compare the volumes of these 14 'acidic' spots in the parents, hybrids and co-electrophoreses (Fig. 2). Mutant, co-electrophoreses 2:1 and 1:2 (mutant:wild type and wild type:mutant, respectively) and wild type defined a scale of $0,1,2$ and 3 doses of wild type allele. A linear relationship was found between the spot volume and the number of doses of the wild type allele, except for polypeptides $1^{-}$in $\mathrm{F} 2,3^{-}, 5^{+}$and $8^{+}$in W64A, and $4^{+}$in both backgrounds (for $4^{+}$and $8^{+}$the regression was only with 1, 2 and 3 doses of the wild type allele because no spot was detected in the mutant) (Table 1 and Fig. 3). Linearity means the absence of a significant staining saturation.

ANOVA were performed to compare the spot volumes between genotypes (wild, mutant and reciprocal hybrids) and between the two backgrounds (F2 and W64A). A background effect appeared for polypeptides $4^{+}, 5^{+}, 7^{+}$and $8^{+}$. Only one weak $(P \geq 0.05)$ genotype $\times$ background interaction was found (polypeptide $6^{+}$). When the mutant was not taken into account because its spot volume was 0 , no genotype effect was found except for polypeptide $4^{+}$in F2, where the wild type differed from the omutant $\times$ owild type hybrid. In all other cases the genotype effect was significant (Table 1), and mostly due to the mutant genotype, as confirmed by $t$-tests.

The expected hybrid values were used as references to test inheritance (see Materials and Methods). In addition to polypeptides $4^{-}, 5^{-}$and $6^{-}$, which were not detected in wild type and hybrids, dominance of the wild type allele was found for the amounts of polypeptides $1^{+}, 2^{+}, 6^{+}, 7^{+}, 8^{+}, 1^{-}$and $2^{-}$(for polypeptides $7^{+}$and $8^{+}$in W64A only) (Fig. 3a, b). For these polypeptides (except $2^{+}$for which the co-electrophoresis displayed an unexpected high value), only one dose of the wild type allele was sufficient to produce hybrid spot volumes undistinguishable from the wild type value and statistically different from the reference hybrid volume.

On the other hand, additive inheritance in 9 mutant $\times \sigma^{*}$ wild type was found for polypeptide $4^{+}$in F2 and for polypeptide $5^{+}$in W64A. Actually it appears from Fig. $3 c$ that there is probably additivity in both backgrounds, at least for polypeptide $5^{+}$, but large residual variance and/or poor estimation of co-electrophoresis spot volumes are likely to be responsible for a lack of statistical evidence. For these two polypeptides in Owild type $\times$ o mutant, as for the remaining polypeptides $\left(3^{+}\right.$in both backgrounds, $3^{-}$in $\mathrm{W} 64 \mathrm{~A}$, and $7^{+}$ 
Table 1 Results of the linearity tests and ANOvA performed on $\log _{10}$ of the standardized spot volumes of polypeptides affected by the 02 mutation in backgrounds $\mathrm{F} 2(F)$ and $\mathrm{W} 64 \mathrm{~A}(W)$

\begin{tabular}{|c|c|c|c|c|c|}
\hline \multirow[b]{2}{*}{ Spot number } & \multirow[b]{2}{*}{$M_{\mathrm{r}}$} & \multirow[b]{2}{*}{ pI } & \multicolumn{3}{|l|}{$F$-values } \\
\hline & & & $\begin{array}{l}\text { Non- } \\
\text { linearity }\end{array}$ & $\begin{array}{l}\text { Linear } \\
\text { regression }\end{array}$ & $\begin{array}{l}\text { Genotype } \\
\text { effect }\end{array}$ \\
\hline $1^{+}$ & 94 & 5.8 & 0.52 & $87.17^{* * *}$ & $21.23^{* * *}$ \\
\hline $2^{+}$ & 34 & 5.9 & 1.08 & $5.98^{*}$ & $12.31^{* * *}$ \\
\hline $3^{+}$ & 47 & 6.1 & 2.26 & $8.30 *$ & $21.17^{* * *}$ \\
\hline \multicolumn{6}{|l|}{$4^{+}$} \\
\hline$F \dagger$ & 47 & 6.2 & 1.05 & 2.81 & $15.02^{* *}$ \\
\hline$W \dagger$ & & & 2.46 & 4.37 & 4.91 \\
\hline \multicolumn{6}{|l|}{$5^{+}$} \\
\hline$F$ & 54 & 5.5 & 0.35 & $8.30^{*}$ & $4.81^{*}$ \\
\hline W & & & $24.29^{* *}$ & $50.93^{* * *}$ & 7.13* \\
\hline $6^{+}$ & 35 & $6.0 / 6.4 \ddagger$ & $<1 \%$ & $19.75^{* *}$ & 0.41 \\
\hline \multicolumn{6}{|l|}{$7^{+}$} \\
\hline$F$ & 35 & 5.8 & 0.16 & $19.53^{* *}$ & $13.90^{* *}$ \\
\hline \multirow{2}{*}{\multicolumn{6}{|c|}{$8^{+}$}} \\
\hline & & & & & \\
\hline$F$ & 35 & 6.1 & 1.16 & $8.96^{*}$ & $6.50^{*}$ \\
\hline$W_{\dagger} \dagger$ & & 6.5 & 1.28 & 2.36 & 0.46 \\
\hline \multicolumn{6}{|l|}{$1^{-}$} \\
\hline$F$ & 34 & 5.3 & $7.12^{*}$ & $45.01^{* * *}$ & $24.13^{* * *}$ \\
\hline $2^{-}$ & 32 & 5.4 & 1.96 & $69.69^{* * *}$ & $27.63^{* * *}$ \\
\hline \multicolumn{6}{|l|}{$3^{-}$} \\
\hline W & 66 & 6.6 & 0.19 & 1.10 & $8.46^{* *}$ \\
\hline $4^{-}$ & 45 & 5.4 & ND & ND & ND \\
\hline $5^{-}$ & 32 & 5.4 & ND & ND & ND \\
\hline $6^{-}$ & 33 & 6.2 & ND & ND & ND \\
\hline
\end{tabular}

$M_{\mathrm{r}}=$ molecular weight in $\mathrm{kDa} ; \mathrm{pI}=$ isoelectric point. ${ }^{*},{ }^{* *}$ and ${ }^{* * *}$, significant at 5,1 and 0.1 per cent, respectively. $\mathrm{ND}=$ not determined, because polypeptides $4^{-}, 5^{-}$ and $6^{-}$were detected in the mutant alone.

tThe mutant was not taken into account because the spot value was 0 .

$\neq$ The first pI refers to the F2 background, the second to the W64A background.

and $8^{+}$in $\mathrm{F} 2$ only) in both hybrids, it was not possible to make a decision between additivity and dominance.

In the cluster including spot $1^{+}$, quantitative analysis was performed for two other close spots. Their variation over the genotypes is tightly parallel to that observed for spot $1^{+}$(Fig. 2), which is consistent with the hypothesis of a protein family with common control.

Using a basic $\mathrm{pH}$ range in the first dimension (IEF) allowed prolamin storage proteins to be resolved. The abundance of 11 polypeptides was reduced by the mutation in W64A as well as in F2. As shown by the specific extraction procedure, nine were $22 \mathrm{kDa}$ zeins, which are known to be affected by the $o 2$ mutation to a greater extent than the $19 \mathrm{kDa}$ zeins (Lee et al., 1976;
Di Fonzo et al., 1977, Martinez-Izquierdo et al., 1984). Moreover one polypeptide spot unique to $o 2$ appeared in close proximity to a zein spot whose intensity decreased relative to the wild type (Fig. 4). Automatic quantification of these basic polypeptides was not attempted, due to an insufficient quality of resolution. As it was not possible to distinguish visually between wild type, hybrids and co-electrophoreses, no conclusion about the inheritance could be drawn.

In order to examine the extent to which the effects of $o 2$ could be due to epistatic interactions, and/or could depend on the 02 allele considered, we visually analysed three additional pairs of near-isogenic lines using the $\mathrm{pH}$ 5-7 IEF range. The effect of the gene substitution was retained in the three backgrounds for 
AI

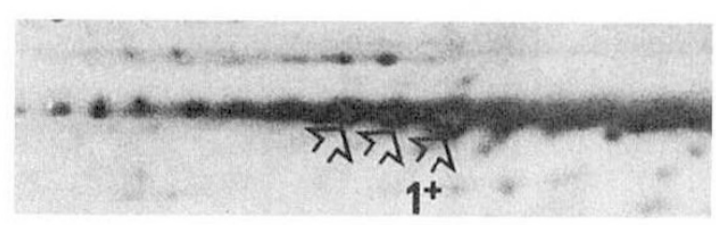

A2

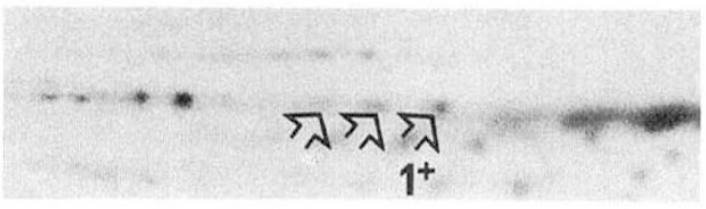

$\mathrm{BI}$

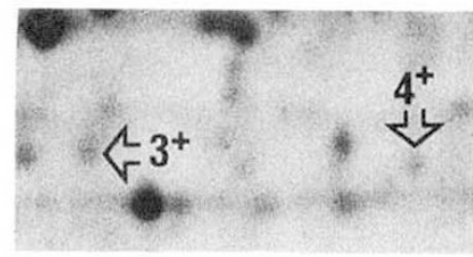

B2

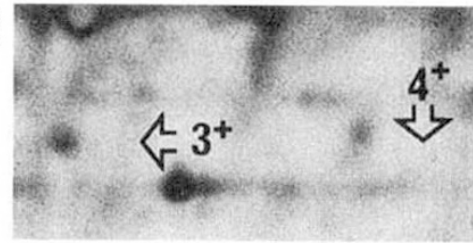

CI

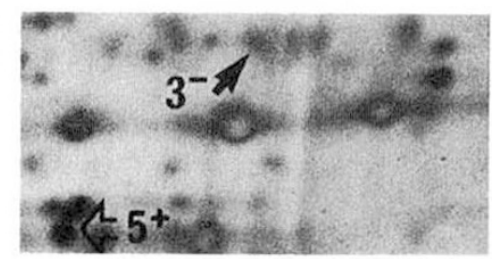

C2

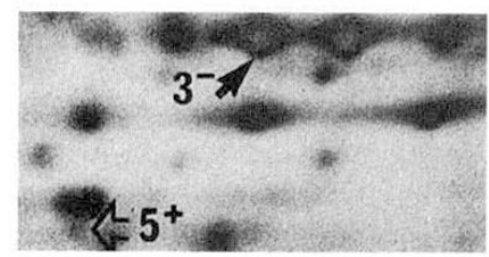

DI

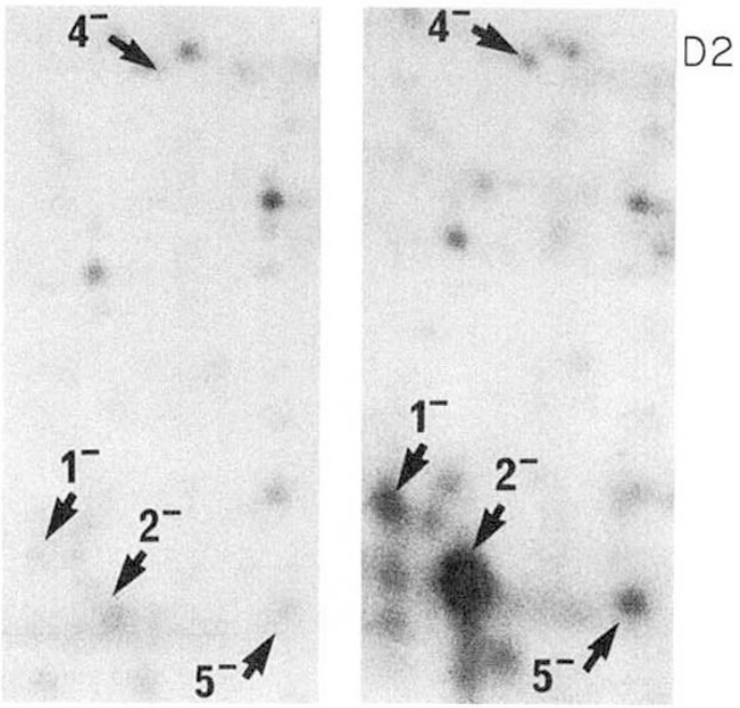

EI

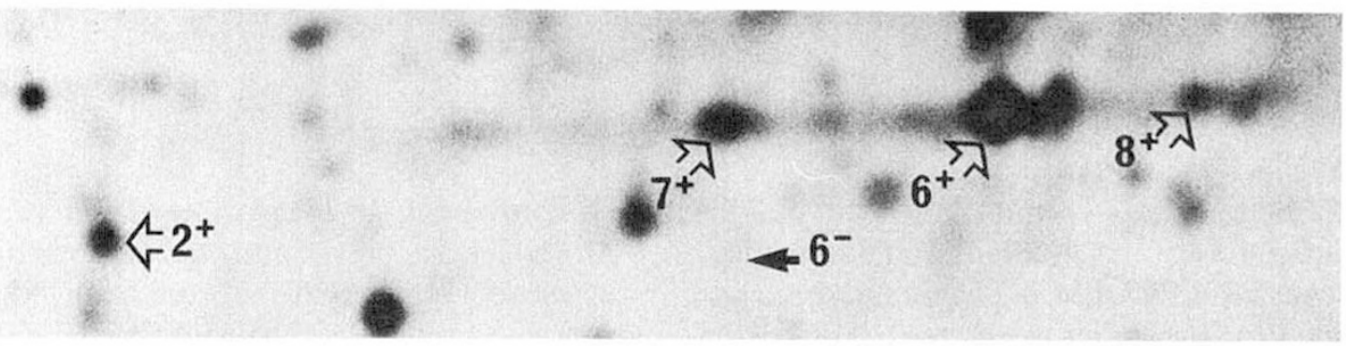

E2

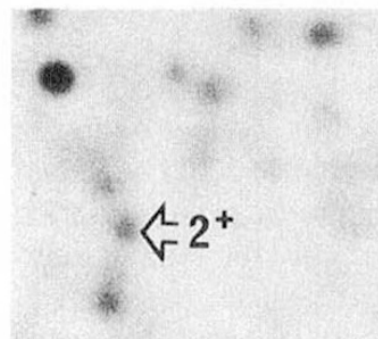

Fig. 1 Details of wild type (A1-E1) and mutant (A2-E2) 2-D gels from W64A isogenic line showing the 14 polypeptides quantified automatically. Empty and black arrows point to spots more intense and less intense in wild type than in mutant, respectively. The two arrows without a number close to $1^{+}$indicate the two other polypeptides analysed in the cluster (see Fig. 2). 
(a)
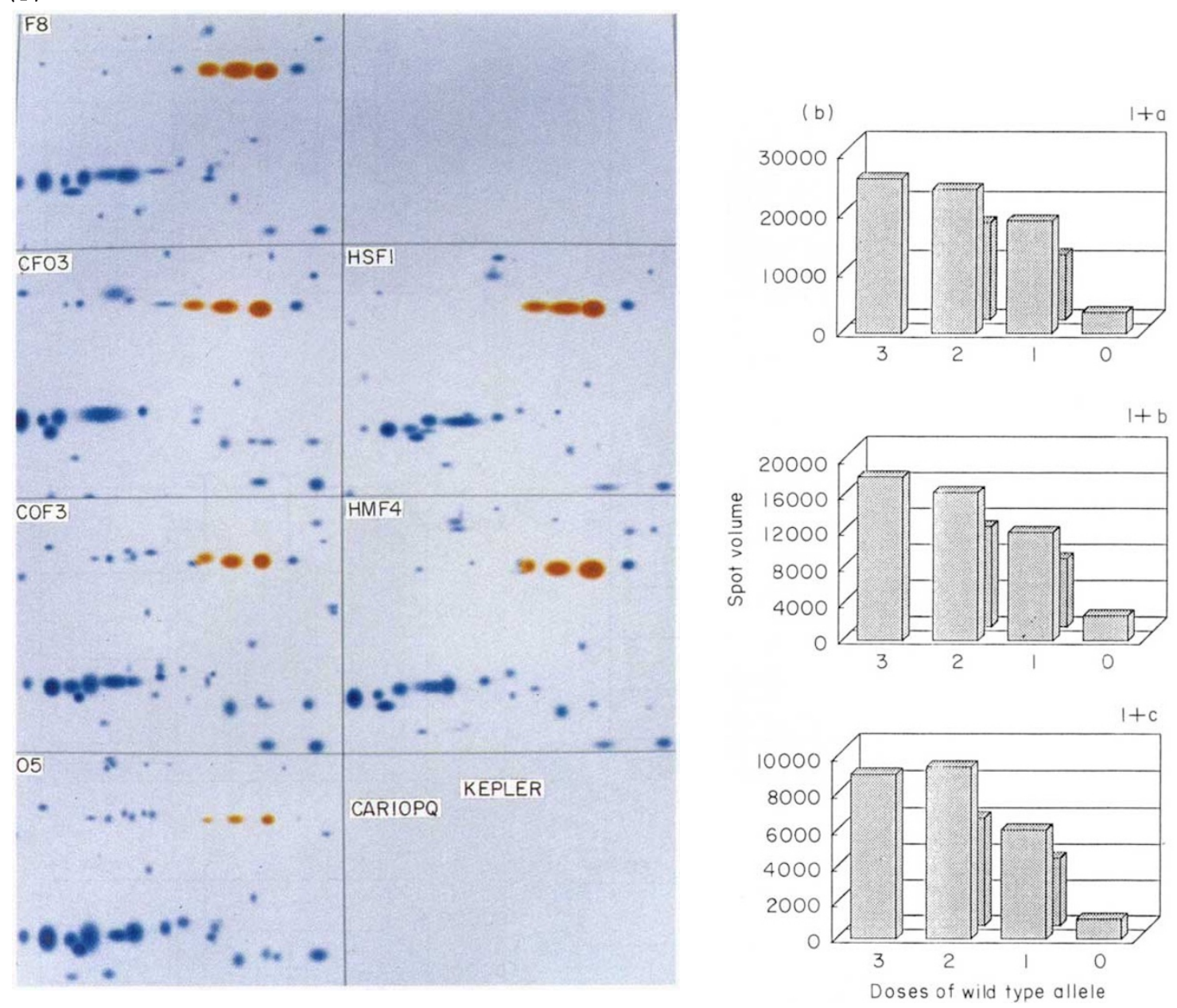

Fig. 2 (a) Synthetic images of the region of the 2-D gels containing spot $1^{+}$. The first column shows the wild type, co-electrophoreses $2: 1$ and $1: 2$, and mutant, and the second one the hybrids $\&$ wild type $\times \sigma$ mutant and $\%$ mutant $\times \varnothing$ wild type (top to bottom). The three orange spots of the cluster were automatically quantified. The most intense is spot $1^{+}$. The decrease in intensity from three doses (wild type) to zero dose (mutant) of wild type allele is visible, as well as the similarity between the hybrids and the wild type. (b) Bar graphs of the mean standardized volumes of spot $1^{+}$and its two companion spots against the number of doses of wild type allele. The expected hybrid volumes are represented behind the experimental hybrid mean volumes.

11 out of 14 polypeptides. Only $3^{-}$and $2^{+}$in W182E and $3^{+}$in $\mathrm{F} 2$ showed no clear difference between the mutant and the wild type (data not shown).

\section{Discussion}

Using isogenic and near-isogenic lines of maize, pleiotropic effects of the $o 2$ mutation on proteins of mature triploid endosperms were assessed by 2-D PAGE. In the genetic background where o2 spontaneously occurred (W64A), the 36 reproducible differences between wild and mutant types can be attributed to direct or indirect effects of $O 2$. More than half of the modifications found in W64A were not detected in F2, where 12 additional changes were observed (allelic differences between W64A and F2, which result in limited shift of spot positions due to charge differences between polypeptides, were not included in this estimate). Differences between the two backgrounds could be explained by possible differences in the effects of the two $o 2$ mutant alleles. Other, non-exclusive possibilities would be that changes unique to $\mathrm{F} 2$ (where $o 2$ was introgressed by eight backcrosses) resulted from effects of genes linked to the introgressed gene, or that the modifications unique to a background would result from epistatic interactions. Other epistatic interactions are revealed by the background effects observed for polypeptides $4^{+}, 5^{+}, 7^{+}, 8^{+}$and $1^{-}$, and by the background $\times$ genotype interaction for polypeptide $6^{+}$. Epistatic interactions for $o 2$ have previously been 

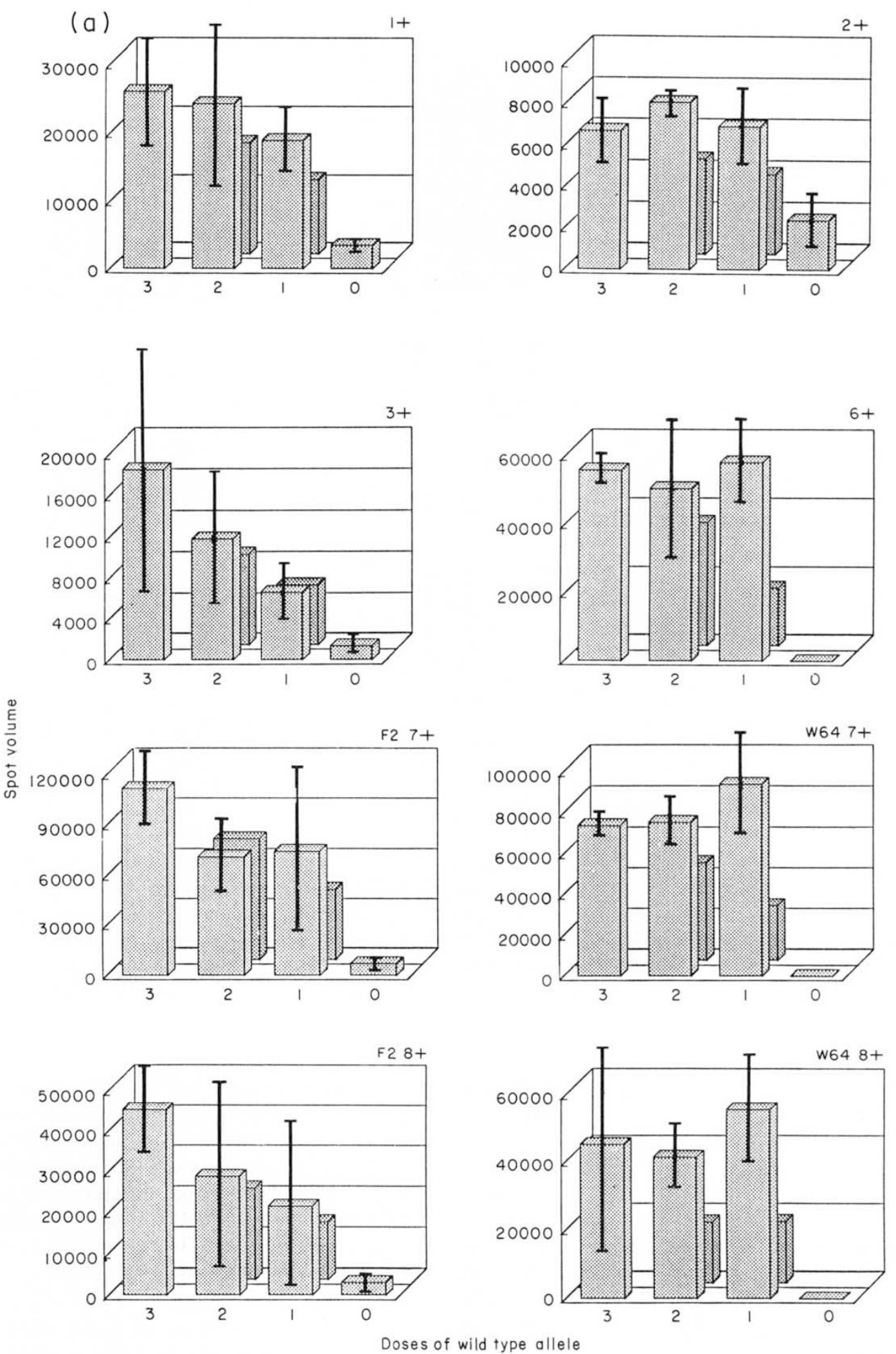

Fig. 3 Bar graphs of the mean standardized volumes of the 14 polypeptide spots affected by $o 2$, against the number of doses of wild type allele. The expected hybrid volumes are represented behind the experimental hybrid mean volumes, except for polypeptides $4^{-}, 5^{-}$and $6^{-}$for which no inheritance analysis was needed because they were detected only in the mutant. (a) Spots more intense in wild type than in mutant, with dominance of the wild type allele. 

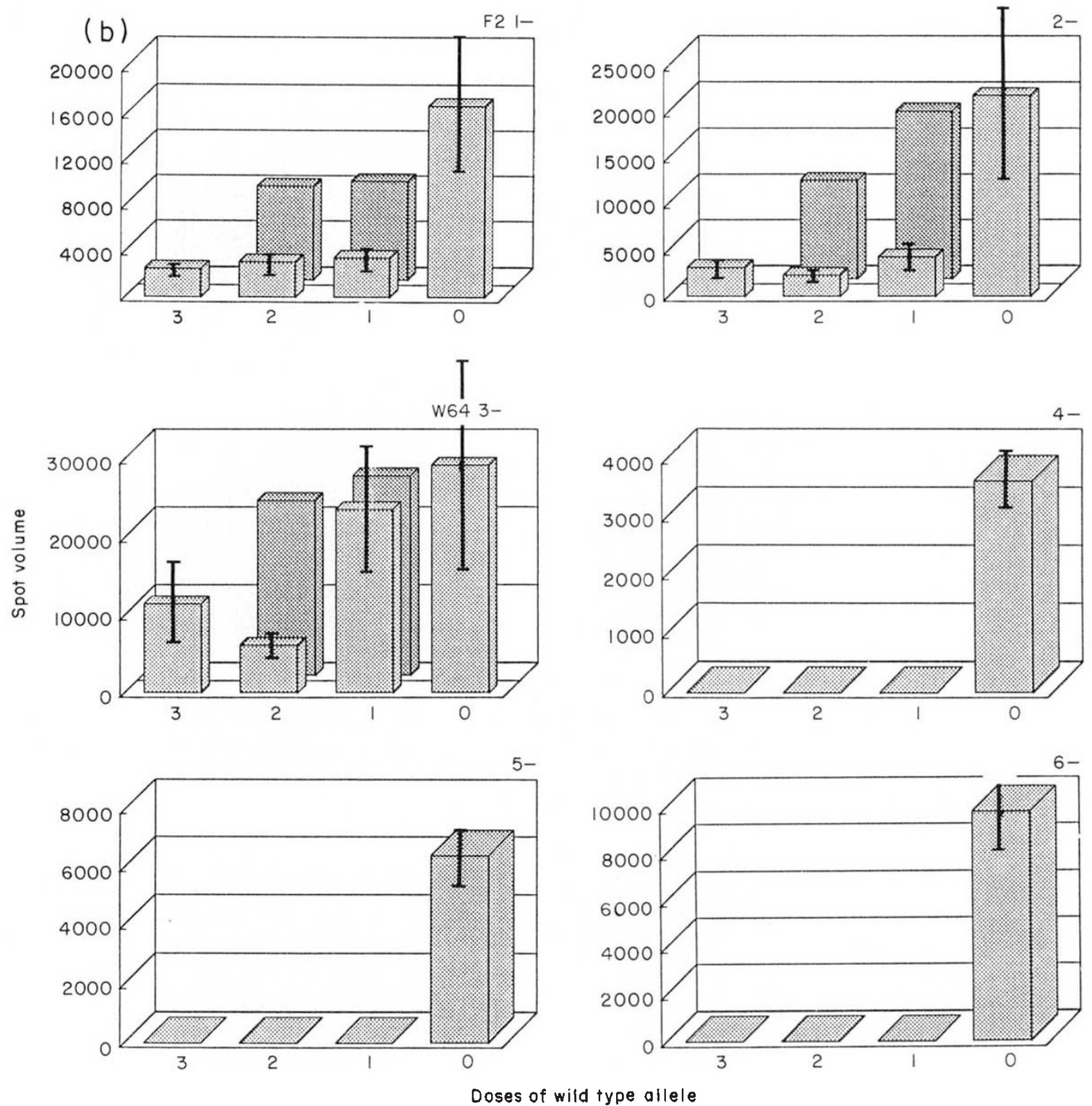

Fig. 3 Bar graphs of the mean standardized volumes of the 14 polypeptide spots affected by $o 2$, against the number of doses of wild type allele. The expected hybrid volumes are represented behind the experimental hybrid mean volumes, except for polypeptides $4^{-}, 5^{-}$and $6^{-}$for which no inheritance analysis was needed because they were detected only in the mutant. (b) Spots less intense in wild type than in the mutant, with dominance of the wild type allele.

documented for ribonuclease activity (Cagampang \& Dalby, 1972), amounts of albumins, globulins, glutelins (Misra \& Mertz, 1975; Dierks-Ventling, 1981) and zeins (Soave et al., 1976).

The amounts of 14 'acidic' polypeptides (or clusters of polypeptides) and 12 'basic' polypeptides were affected by the gene substitution in both F2 and W64A backgrounds. Some of these polypeptides, $22 \mathrm{kDa}$ zeins, b-32 and globulins, were identified by specific extraction or western blotting. The 14 'acidic' polypeptide spots were retained for automatic quantification analysis. Note that the variation of most of them was not restricted to these two backgrounds. A visual survey of three other pairs of near-isogenic lines revealed that 11 differences out of the 14 found were detected in the five backgrounds, the remaining three being detected in four out of the five backgrounds. Therefore, irrespective of the $o 2$ alleles and backgrounds, a set of more than 10 polypeptides seemed to be consistently affected.

The $O 2$ gene product has been shown to belong to the basic region-leucine zipper (bZip) family of transcription activators (Hartings et al., 1989; Schmidt et al., 1990 ), and is able to bind to specific regions on the $5^{\prime}$ 
(c)

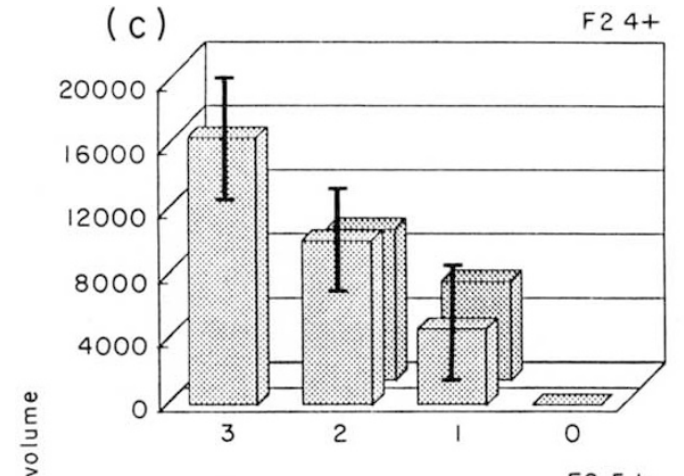

흥

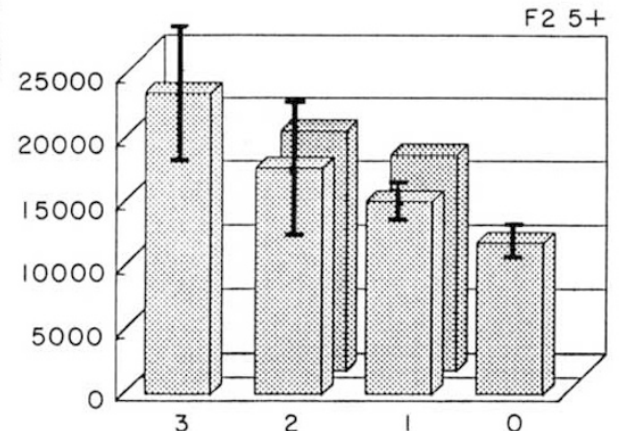

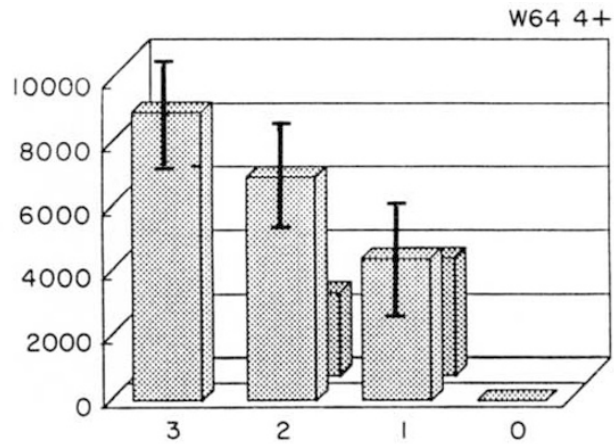

W64 $5+$

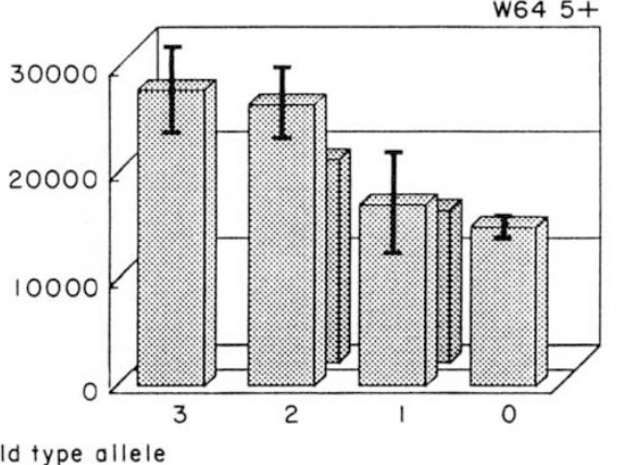

Fig. 3 Bar graphs of the mean standardized volumes of the 14 polypeptide spots affected by $o 2$, against the number of doses of wild type allele. The expected hybrid volumes are represented behind the experimental hybrid mean volumes, except for polypeptides $4^{-}, 5^{-}$and $6^{-}$for which no inheritance analysis was needed because they were detected only in the mutant. (c) Spots more intense in wild type than in mutant, with co-dominant inheritance.

(a)

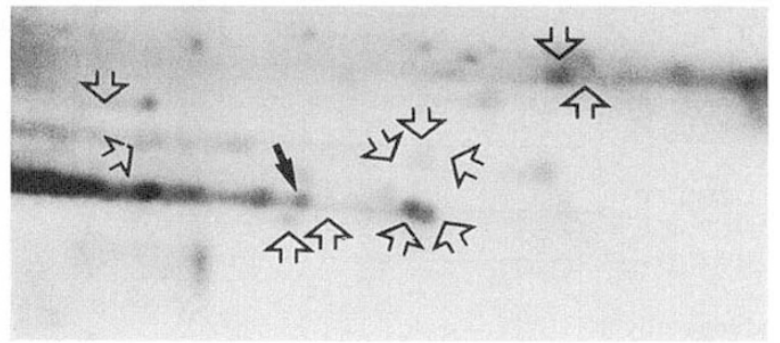

( b )

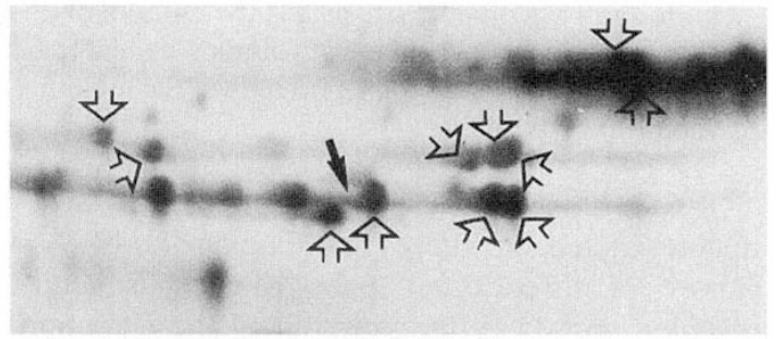

Fig. 4 Two-dimensional gels of endosperm proteins of the near-isogenic lines $\mathrm{F} 2 \mathrm{O} 2$ (a) and $\mathrm{F} 202$ (b) (basic pH range). Empty and black arrows point to spots more intense and less intense in the wild type than in the mutant, respectively.

side of the coding sequence of a $22 \mathrm{kDa}$ zein genomic clone (Schmidt et al., 1990) but not to the promoter of the $19 \mathrm{kDa}$ zein genes (Birchler, 1990). The regulatory properties of the $\mathrm{O} 2$ protein probably explain the multiple effects and also the different consequences of $o 2$ already documented. Relationships among some effects are straightforward. An increase in lysine content results from an increase in the ratio of globulins and glutelins to zein, which are lysine-poor proteins (Concon, 1966). However, the basis of most of the effects remains obscure. For example the alteration of the photosynthetic capacity is all the more difficult to explain since the $O 2$ gene does not appear to be expressed in the leaves (Schmidt et al., 1987).

Higher amounts of gene products in the wild type than in the mutant could simply be due to a direct action of the transcription activator, as shown for 22 kDa zeins (Kodrzycki et al., 1989). For six acidic and one basic polypeptides, the amount of which was increased in the mutant, such a hypothesis cannot be retained unless $\mathrm{O} 2$ does not act as an activator; for example oncoprotein Fos, a bZip factor, has been shown to act as a positive or negative regulator in different DNA contexts (Curran \& Franza, 1988; Vogt \& Bos, 1989). However indirect effects can also be involved for any affected polypeptide, and especially for the 3 ones whose variation did not seem to be retained over all the backgrounds analysed. $\mathrm{O} 2$ could act via other gene products, which in turn could act either positively or negatively. In this regard 02 is 
known to interact with other kernel composition mutants, some of which are regulatory in nature (Di Fonzo et al., 1986; Lee et al., 1976; Misra \& Mertz, 1975; Tsai et al., 1978; Lee \& Tsai, 1984). Moreover a higher level of ribonuclease activity has been found in mutant genotypes (Dalby \& Davies, 1967), which supports the hypothesis of a partial non-transcriptional control of zein expression (Lee \& Tsai, 1984). On the other hand, far reaching effects of $o 2$ could occur through metabolic rather than transcriptional control. As 02 genotypes show a dramatic reduction in zein content, the differences we found could be secondary consequences of this important physiological variation. However, as we used only the relative values of polypeptide amounts, we probably did not take into account any global effect on protein abundance.

A trans-acting, non-limiting transcription factor should result in dominance of the wild type allele for all the affected characters. This does not seem to be well documented for macroscopic traits, even though $\mathrm{O} 2$ is dominant over $o 2$ for endosperm appearance. Visual examination of spot intensities suggested different kinds of inheritance for the amount of polypeptides affected by $o 2$ mutation (see also Fig. 3). Automatic quantification allowed dominance to be demonstrated for 10 polypeptides among the 14 acidic ones, and additive inheritance for the amount of polypeptides $4^{+}$ and $5^{+}$. That the $\mathrm{O} 2$ gene product could sometimes be slightly limiting is further suggested by the fact that the two reciprocal hybrids were classified as expected under the hypothesis of a dose effect of the $O 2$ gene product in 12 cases out of 15 , even though for each polypeptide individually the differences between the reciprocal hybrids are usually not statistically significant (Fig. 3). Note that the dose effect of $O 2$ was previously reported on the amount of particular amino acids of endosperm proteins (Bates, 1966) and on the amount of b-32 protein in developing endosperms (Soave et al., 1981). Floury-2, another gene controlling zein accumulation, has also been found to display a dose effect (Fornasari et al., 1982). That in neither case is $o 2$ dominant over $O 2$ suggests that neither $o 2$ allele codes for a defective protein acting as a trans-dominant inhibitor because it dimerizes with the wild type protein to block activation (Smeal et al., 1989).

Two-dimensional electrophoresis on isogenic lines represents a general procedure to identify products of genes directly or indirectly controlled by a given transcription factor. This is particularly interesting in connection with methods now available for obtaining $\mathrm{N}$-terminal or internal amino acid sequence information from microgram amounts of protein in a single spot, which can aid in gene isolation through the use of synthetic oligonucleotides or through the use of anti- sera of predetermined specificity (Aebersold et al., 1987; Bauw et al., 1989). Moreover computer-assisted analysis of 2-D PAGE patterns proves to be a powerful tool for the quantitative analysis of regulatory processes. It revealed a complex mode of action of the transcription factor encoded by the $O 2$ gene. First, $o 2$ has opposite effects according to the gene product affected. At the protein phenotype level, this appears to be reminiscent of antagonistic pleiotropy (Wright, 1977; Rose, 1982). Secondly, pleiotropically related variations display different types of inheritance. To our knowledge, this is the first evidence for such a phenomenon at the gene product level. If it were common, it could have interesting genetic or physiological consequences. In case of similar inheritance, the heterozygote lies on the line joining the two homozygotes in the $n$-dimensional space defined by the amounts of the $n$ proteins affected by the mutation. In case of different inheritance, the heterozygote can be found on any point of the hypervolume (a mathematical 'simplex') where the $2^{n}$ vertices correspond to all possible combinations of complete dominance or recessivity for the $n$ proteins. In the context of combinatorial or synergistic gene regulation, where the specificity of expression arises from the coordinate presence of two or more factors of restricted specificity (Yamamoto, 1985; Rabilloud et al. 1991), this geometrical description may be useful to realize the extent to which an heterozygote, compared to its parents, can display unpredictable patterns of genetic expression whenever different types of inheritance result in a particular distribution of factors. Even though the $\mathrm{O} 2$-affected proteins which we revealed are probably not involved in combinatorial regulation processes, the question arises concerning the possible metabolic or phenotypic consequences of the original distribution observed in the hybrids. Recent data in maize showed that the polymorphism of the amounts of covariable proteins could be involved in agromorphological variation and hybrid vigour (Damerval, et al., 1987b; Leonardi et al., 1991). If this observation proved to be of general value, our results, beyond the case of $O 2$, could be relevant to the questions of selective values, maintaining polymorphisms and heterosis.

\section{Acknowledgements}

We would like to thank Dr Michel Zivy for his invaluable help with computer-assisted analysis of the 2-D gels, Joël Blaisonneau and Marie-Pierre Digard for their expert technical assistance, Martine Le Guilloux and Jean-Marc Josse for the figures, and an anonymous reviewer for very constructive comments. 


\section{References}

AEBERSOLD, R. H., LEAVITT, J., SAAVEDRA, R. A., HOOD, L. E. AND KENT, S. B. H. 1987. Internal amino acid sequence analysis of proteins separated by one or two-dimensional gel electrophoresis after in situ protease digestion on nitrocellulose. Proc. Natl. Acad. Sci., U.S.A., 84, 6970-6974.

Allison, A. C. 1955. Aspects of polymorphism in man. Cold Spring Harbor Symp. Quant. Biol., 20, 239-255.

ALLISON, A. C. 1964. Polymorphism and natural selection in human populations. Cold Spring Harbor Symp. Quant. Biol., 29, 137-149.

ANDERSON, L., HOFMANN, J. P., ANDERSON, E., WALKER, B. AND ANDERSON, N. G. 1989. Technical improvements in 2-D gel quality and reproducibility using the Iso-Dalt ${ }^{\circledR}$ system. In: Endler, A. T. and Hanash, S. (eds) Two-dimensional Electrophoresis, Proceedings of the International Twodimensional Electrophoresis Conference, Vienna 1988 VCH, D-690 Weinheim, Germany pp. 288-297.

ANDERSON, N. L., NANCE, S. L., TOLlaKSEN, S. L., GIERE, F. A. AND ANDERSON, N. G. $1985 \mathrm{a}$. Quantitative reproducibility of measurements from Coomassie Blue-stained two-dimensional gels: analysis of mouse liver protein patterns and a comparison of BALB/c an C57 strains. Electrophoresis, 6 , 592-599.

ANDERSON, N. G., TOLLAKSEN, S. L., PASCOE, F. H. AND ANDERSON, N. L. 1985b. Two-dimensional electrophoresis analysis of wheat seed proteins. Crop Sci., 25, 667-674.

BATES, L. S. 1966. Amino acid analysis, In: Mertz, E. T. and Nelson, O. E. (eds) Proceedings of the High Lysine Corn Conference, Corn Industries Research Foundation Publication. Washington, DC, pp. 61-66.

BAUW, G. J., VAN DAMME, J., PUYPE, M., VANDEKERKHOVE, J., GESSER, B., RATZ, G. P., LAURIDSEN, J. B. AND CElis, J. E. 1989. Protein electroblotting and microsequencing strategies in generating protein data bases from two-dimensional gels. Proc. Natl. Acad. Sci., U.S.A., 86, 7701-7705.

BHATTACHARYYA, M. K., SMITH, A. M., ELLIS, T. H. N., HEDLEY, C. AND MARTIN, C. 1990. The wrinkled-seed character of pea described by Mendel is caused by a transposon-like insertion in a gene encoding starch-branching enzyme. Cell, 60 , $115-122$.

BIRCHLER, J. 1990. Amazing results. Trends Genet., 6, 231-233.

CAGAMPANG, G. B., AND DALBY, A. 1972. Development of ribonuclease activity in 9 inbred lines of normal and opaque-2 maize. Can. J. Plant. Sci., 52, 901-905.

CASPARI, E. 1952. Pleiotropic gene action. Evolution, 6, 1-18. CHRISTIANSON, D. D., KHOO, U., NIELSEN, H. C. AND WALL, J. S. 1974. Influence of Opaque-2 and Floury-2 genes on formation of proteins in particulates of corn endosperm. Plant Physiol., 53, 851-855.

CONCON, J. M. 1966. The proteins of Opaque-2 maize, In: Mertz, E. T and Nelson O. E. (eds) Proceedings of the High Lysine Corn Conference, Corn Industries Research Foundation Publication, Washington, DC, pp. 67-73.

CURRAN, T. AND FRANZA, Jr., R. B. 1988. Fos and Jun: the AP-1 connection. Cell, 55, 395-397.

DALBY, A. AND DAVIES, 1. A. I. 1967. Rjbonuclease activity in the developing seeds of normal and opaque-2 maize. Science, 155, 1573-1575.

DAMER VAL, C., DE VIENNE, D., ZIVY, M. AND THIELLEMENT, H. 1986. Technical improvements in two-dimensional electrophoresis increase the level of variation detected in wheat seedling proteins. Electrophoresis, 6, 52-54.

DAMERVAL, C., HEBERT, Y. AND DE VIENNE, D. $1987 \mathrm{~b}$. Is the polymorphism of protein amounts related to phenotypic variability? A comparison of two-dimensional electrophoresis data with morphological traits in maize. Theor. Appl. Genet., 74, 194-202.

DAMER VAL, C., LE GUILlOUX, M., BLAISONNEAU, J. AND DE VIENNE, D. 1987a. A simplification of the Heukeshoven and Dernick's silver staining of proteins. Electrophoresis, 8, 158-159.

DIERKS-VENTLING, c. 1981. Storage proteins in Zea mays (L.): interrelationship of albumins, globulins and zeins in the Opaque-2 mutation. Eur. J. Biochem., 120, 177-182.

DI FONZO, N., FORNASARI, E. SALAMINI, F. 1977. SDS-Protein subunits in normal opaque-2 and floury-2 maize endosperms. Maydica, 22, 77-88.

Di FONZO, N., HARTINGS, H., BRIMBILl.A, M., MOTTO, M., SOAVE, C., NAVARRo, E., PALAU, J., RHODE, W. AND SALAMinI, F. 1988. The b-32 protein from maize endosperm, an albumin regulated by the $O 2$ locus: nucleic acid (cDNA) and amino acid sequences. Mol. Gen. Genet., 21 2, 481-487.

DI FONZO, N., MANZOCCHI, L., SALAMINI, F. AND SOAVE, C. 1986. Purification of an endospermic protein of maize associated with the Opaque- 2 and Opaque- 6 genes. Planta, 167, 587-594.

FORNASARI, E., DI FONZO, N., SALAMINI, F., REGGIANI, R. AND SOAVE, C. 1982. Floury-2 and Opaque-7 interaction in the synthesis of zein polypepides. Maydica, 27, 185-189.

GotTliEB, L. D. AND DE VIENNE, D. 1988. Assessment of pleiotropic effects of a gene substitution in Pea by two-dimensional polyacrylamide gel electrophoresis. Genetics, 119 , 705-710.

GRANIER, F. AND DE VIENNE, D. 1986. Silver staining of proteins: standardized procedure for two-dimensional gels bound to polyester sheets. Anal. Biochem., 155, 45-50.

GUPTA, D. 1979. Shortening of protandry by opaque-2 mutant gene. Indian J. Genet. Plant Breed., 39, 230-233.

HARTINGS, H., MADDALONI, M., LAZZARONI, N., DI FONZO, N., MOTTO, M., SALAMINI, F. AND THOMPSON, R. 1989. The $O 2$ gene which regulates zein deposition in maize endosperm encodes a protein with structural homologies to transcriptional activators. $E M B O J ., \mathbf{8}, 2795-2801$.

HIGGinBothaM, J. W., SMITH, J. S. C. AND SMITH, o. s. 1991. Quantitative analysis of two-dimensional protein profiles of inbred lines of maize (Zea mays L.). Electrophoresis, 12, 425-431.

HOPE, I. A. AND STRUHL, K. 1985. GCN4 protein, synthesized in vitro, binds HIS3 regulatory sequences: implications for general control of amino acid biosynthetic genes in yeast. Cell, 43, 177-188.

KEIGHTLEY, P. D. AND KACSER, H. 1987. Dominance, pleiotropy and metabolic structure. Genetics, 117, 319-329.

KODRZYCKI, R., BOSTON, R. S. AND LARKINS, B. A. 1989. The opaque-2 mutation of maize differentially reduces zein gene transcription. The Plant Cell, 1, 105-114. 
LAMBERT, R. J., ALEXANDER, D. E. AND DUDLEY, J. w. 1969. Relative performance of normal and modified protein (opaque2) maize hybrids. Crop Sci., 9, 242-243.

LEE, R. H., JONES, R. A., DALBY, A. AND TSAI, C. Y. 1976. Genetic regulation of storage protein content in maize endosperm. Biochem, Genet., 14, 641-650.

LEE, L. AND TSAI, C. Y. 1984. Effect of RNase on zein synthesis in endosperm of brittle-2; opaque-2 maize double mutant. Plant Physiol., 76, 79-83.

LEONARDI, A., DAMERVAL, C., HEBERT, Y., GALlAIS, A. AND DE VIENNE, D. 1991. Association of protein amount polymorphism (PAP) among maize lines with performance of their hybrids. Theor. Appl. Genet., 82, 552-560.

LOESCH, P. J., JR., FOLEY, D. C. AND COX, D. F. 1976. Comparative resistance of Opaque- 2 and normal inbred lines of maize to ear-rotting pathogens. Crop. Sci., 16, 841-842.

MARTINEZ-IZOUIERDO, J. A., LUDEVID, M. D., PUIGDOMENECH, P. AND PALAU, J. 1984. Two-dimensional gel electrophoresis of zein proteins from normal and opaque-2 maize with non ionic detergent acid urea-polyacrylamide gel electrophoresis in the first dimension. Plant Sci., 34, 43-50.

MERTZ, E. T., BATES, L. S. AND NELSON, O. E. 1964. Mutant gene that changes protein composition and increases lysine content of maize endosperm. Science, 145, 279-280.

MISRA, P. S. AND MERTZ, E. T. 1975. Studies on corn proteins. VI. Endosperm protein changes in single and double endosperm mutants of maize. Cereal. Chem., 52, 161-167.

MOROT-GAUDRY, J. F., FARINEAU, J. AND JOLIVET, E. 1979. Effect of leaf position and plant age on photosynthetic carbon metabolism in leaves of 8 and 16 day-old maize seedlings (W64A) with and without the gene Opaque-2. Photosynthetica, 13, 365-375.

NEUHOFF, V., AROLD, N., TAUBE, D. AND EHRHARDT, W. 1988. Improved staining of proteins in polyacrylamide gels including isoelectric focusing gels with clear background at nanogram sensitivity using Coomassie Brilliant Blue G-250 and R-250. Electrophoresis, 9, 255-262.

O'FARRELl, P. H. 1975. High resolution two-dimensional electrophoresis of proteins. J. Biol. Chem., 250, 4007-4021.

RABILLOUD, T., PENNETIER, J. L., HIBNER, U., VINCENS, P., TARROUX, P. AND ROUGEON, F. 1991. Stage transitions in B-lymphocyte differentiation correlate with limited variations in nuclear proteins. Proc. Natl. Acad. Sci., U.S.A ., 88, 1830-1834.

RIGHETT,, P. G., GIANAZZA, E., VIOTTI, A. AND SOAVE, C. 1977. Heterogeneity of storage proteins in maize. Planta, 136, 115-123.

RoSE, M. R. 1982. Antagonistic pleiotropy, dominance, and genetic variation. Heredity, 48, 63-78.

SASSONE-CORSI, P. 1985. Pleiotropic action of the adenovirus E1 A proteins. Trends Genet., 1, 98-99.

SCHMIDT, R. J., BURR, F. A., AUKERMAN, M. J. AND BURR, B. 1990. Maize regulatory gene opaque- 2 encodes a protein with 'leucine-zipper' motif that binds to zein DNA. Proc. Natl. Acad.Sci., U.S.A., 87, 46-50.
SCHMIDT, R. J., BURR, F. A. AND BURR, B. 1987. Transposon tagging and molecular analysis of the maize regulatory locus opaque-2. Science 238, 960-963.

SCOPES, R. K. 1974. Measurement of protein by spectrophotometry at $205 \mathrm{~nm}$. Anal. Biochem., 59, 277--282.

SMEAL, T., ANGEL, P., MEEK, J. AND KARIN, M. 1989. Different requirements for formation of Jun:Jun and Jun:Fos complexes. Genes Dev., 3, 2091-2100.

SOAVE, C., RIGHETTI, P. G. LORENZONI, C., GENTINETTA, E. AND SALAMINI, F. 1976. Expressivity of the opaque-2 gene at the level of zein molecular components. Maydica, 21, 61-75.

SOAVE, C., TARDINI, L., DI FONZO, N. AND SALAMINI, F. 1981. Zein level in maize endosperm depends on a protein under control of the opaque-2 and opaque-6 loci. Cell, 27, 403-410.

SOKAL, R. R. AND RoHLF, F. J. 1969. Biometry: the Principle and Practice of Statistics in Biological Research. Freeman, San Francisco.

TSAI, C. Y., LARKINS, B. A. AND GLOVER, D. v. 1978. Interaction of the Opaque-2 gene with starch-forming mutant genes on the synthesis of zein in maize endosperm. Biochem. Genet., 16, 883-896.

VARAGONA, M. J., SCHMIDT, R. J. AND RAIKHEL, N. v. 1991. Monocot regulatory protein Opaque- 2 is localized in the nucleus of maize endosperm and transformed tobacco plants. The Plant Cell, 3, 105-113.

VIENNE, D. DE, AND GOTTLIEB, L. D. 1990. Comparison of leaflets and tendrils in wild-type and homeotic mutant morphs of pea by two-dimensional electrophoresis of proteins. $J$. Hered., 81, 117-122.

VITALE, A., SOAVE, C. AND Galante, E. 1980. Peptide mapping of IEF zein components from maize. Plant Sci. Lett., 18, $57-64$

VOGT, P. K., AND BOS, T. J. 1989. The oncogene jun and nuclear signalling. Trends Biochem. Sci., 14, 172-175.

WALL, J. S., FEY, D. A. AND PAULIS, J. w. 1984. Improved twodimensional electorophoretic separation of zein proteins: application to study of zein inheritance in corn genotypes. Cereal. Chem., 61, 141-146.

WEIDNER, E. vON, 1950. Die Manifestation von Gen $R i$ bei der komplexheterozygoten Eu-Oenothera l. I. Biol. Zbl., 69, 478-499.

WOMACK, J. E., YAN, D. L. S. AND M. POTIER, M. 1981. Gene for neuraminidase activity on mouse chromosome 17 near H-2: pleiotropic effects on multiple hydrolases. Science, 212, 63-65.

WRIGHT, s. 1968. Evolution and the Genetics of Populations. Vol. 1. The University of Chicago Press, Chicago, IL.

Wright, s. 1977. Evolution and the Genetics of Populations. III. Experimental Results and Evolutionary Deductions. pp. 557. University of Chicago Press, Chicago, IL.

YAMAMOTO, K. R. 1985. Steroid receptor regulated transcription of specific genes and gene networks. Ann. Rev. Genet., 19, 209-252. 